ABDI: Jurnal Pengabdian dan Pemberdayaan Masyarakat ISSN: 2656-369X (Print), 2684-8570 (Online)

Volume 1 No. 2, Desember 2019

http://abdi.ppj.unp.ac.id/index.php/abdi

Email: abdi@ppj.unp.ac.id

DOI: https://doi.org/10.24036/abdi.vli2.19

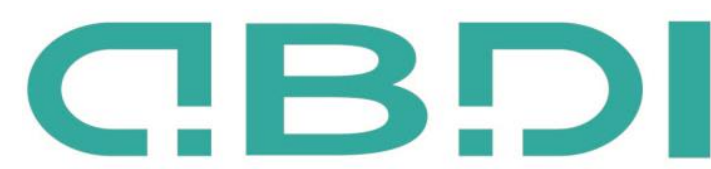

ABDI: JURNAL PENGABDIAN DAN PEMBERDAYAAN MASYARAKAT

\title{
Makerspace Sebagai Media Literasi Untuk Perpustakaan Sekolah
}

\author{
Riya Fatmawati ${ }^{1}$, Malta Nelisa ${ }^{2}$, Habiburrahman ${ }^{3}$. \\ ${ }^{1,2,3}$ Jurusan Bahasa Indonesia Universitas Negeri Padang \\ E-mail: riyafatmawati@fbs.unp.ac.id.
}

\begin{abstract}
Abstrak
Tulisan ini bertujuan untuk meningkatkan jumlah pengunjung pada perpustakaan sekolah SMPN 1 Nan Sabaris dengan cara menambah layanan pada Perpustakaan Sekolah SMPN 1 Nan Sabaris Kecamatan Nan Sabaris Kabupaten Padang Pariaman. Target yang ingin dicapai adalah memberikan ruang makerspace kepada siswa sehingga siswa mempunyai sebuah ruang kreatifitas untuk menuangkan ide-ide dan kreatifitas di perpustakaan sekolah. Metode yang digunakan dalam penelitian ini adalah metode kualitatif dengan proses pengambilan data dilakukan dengan cara wawancara dan observasi lapangan. Hasil yang diperoleh dalam kegiatan ini adalah bertambahnya jumlah pengunjung perpustakaan dan tersedianya sebuah ruang pada perpustakaan sekolah sebagai salah satu bentuk layanan terbaru yang disebut dengan layanan makerspace.
\end{abstract}

Kata kunci: Makerspace, Perpustakaan, Sekolah.

\section{Abstract}

This paper aims to increase the number of visitors to the Nan Sabaris SMPN 1 school library by adding services to the Nan Sabaris SMPN 1 School Library, Nan Sabaris District, Padang Pariaman Regency. The target to be achieved is to provide a maker space for students so that students have a space for creativity to express ideas and creativity in the school library. The method used in this study is a qualitative method with the process of collecting data by interview and field observation. The results obtained in this study are the increasing number of library visitors and the availability of a space in the school library as one of the newest forms of service called makerspace services.

Key Word: Library, Makerspace, School

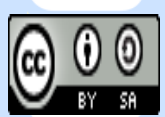

Revised: 4 Desember 2019

Available Online: 6 Desember 2019 


\section{Pendahuluan}

Makerspace adalah sebuah ruang yang dirancang khusus bagi para individu pembuat produk. Makerspace merupakan istilah yang sudah familiar di negara Amerika dan Inggris yang menyediakan tempat khusus dan didesain secara khusus bagi orang-orang untuk mengeluarkan ide dan berkreasi. Menurut Chan dan Poddick, (2014) mengatakan makerspace merupakan konsep dan latar belakang ruang kegiatan pada sebuah perpustakaan yang menyediakan alat-alat atau perangkat-perangkat yang bisa digunakan, kegiatan pada ruang makerspace adalah selain mencoba mengotak-atik barang yang sudah ada bisa juga membuat kreasi baru yang mungkin belum pernah ada sebelumnya. Makerspace sangat membantu siswa dalam menuangkan ide-ide yang mereka miliki, dan bisa mengasah dan mengembangkan keterampilan yang ada sehingga siswa dibekali dengan keterampilan yang bermanfaat.

Berdasarkan penelitian Mann, L. (2018) yang dilakukan di Texas pada tahun 2018 mengatakan $65 \%$ pada saat ini anak usia sekolah akan lebih mapan dalam bekerja dan berkarir jika mereka tidak hanya fokus pada penelusuran informasi akan tatapi memiliki karya dan mempunyai keterampilan. Oleh sebab itu, ada baiknya di perpustakaan sekolah disediakan layanan makerspace yang bisa menambah keterampilan siswa karena ruang makerspace tidak hanya untuk sekedar ruang mendapatkan informasi saja akan tetapi mereka bisa mengolah informasi tersebut menjadi sebuah kreatifitas yang bisa menambah keterampilan, tidak hanya itu pengelola perpustakaan sekolah dituntut lebih bisa mengembangkan diri dan memiliki keteampilan khusus yang bisa dibagi untuk siswa yang datang keperpustakaan, pengelola perpustakaan dituntut untuk memenuhi layanan perpustakaan yang sesuai dengan trend dan perkembangan zaman. Adapun salah satu model layanan perpustakaan terbaru saat ini adalah perpustakaan mempunyai sebuah ruang untuk makerspace.

Makerspace bisa menjadikan perpustakaan menjadi sebuah ruangan yang siap berinteraksi dengan antar pengunjung lainnya, dan tidak lagi menjadikan perpustakaan sebagai ruang senyap, melainkan sebagai ruang yang penuh dengan ekspresi dan terbuka bagi siapa saja untuk menembangkan diri dan berkreatifitas dengan menghasilkan produk-produk inovatif terbaru.

Menurut Yusuf (2007:2) perpustakaan sekolah adalah perpustakaan yang ada dilingkungan sekolah yang bertujuan untuk memenuhi kebutuhan informasi bagi masyarkat dilingkungan sekolah yang bersangkutan. Hal senada juga tertera dalam Standar Perpustakaan Sekolah (SNI 7329-2009), perpustakaan sekolah bertujuan menyediakan pusat sumber belajar sehingga dapat membantu pengembangan dan peningkatan minat baca, literasi informasi, bakat, dan kemampuan peserta didik. Perpustakaan sekolah bertujuan Untuk menyediakan sumber informasi dan tempat belajar sehingga dapat membantu mengembangkan dan meningkatkan minat baca dan mengembangkan pengetahuan yang sudah ada.

Berdasarkan observasi awal pada perpustakaan SMPN 1 Nan Sabaris Kabupaten Padang pariaman ditemukan permasalahan sebagai berikut, pertama kurang maksimalnya layanan yang diberikan oleh pengelola perpustakaan sekolah kepada siswa, hal ini terlihat dari jenis layanan yang ada pada perpustakaan sekolah yang menyediakan layanan baca ditempat dan layanan peminjaman. Untuk layanan baca siswa hanya bisa menggunakan waktu istrihat saja sehingga ini sangat menghambat siswa untuk melakukan aktifitas membaca di sekolah. Sedangkan untuk layanan peminjaman hanya boleh dilakukan oleh wali kelas siswa dan hal ini sangat tidak memungkinkan siswa dapat berkembang dan memiliki keterampilan.

Tabel 1. Jenis Layanan yang ada pada perpustakaan sekolah SMPN 1 Nan Sabaris

\begin{tabular}{llc}
\hline No. & Jenis Layanan & Jam Buka \\
\hline 1. & Layanan Baca & Senin-Jumat \\
& & $08.00-13.00$ \\
\hline 2. & Layanan Sirkulasi & Senin-jumat \\
& & $08.00-13.00$ \\
\hline
\end{tabular}

Dari table diatas dapat dilihat bahwa jenis layanan yang ada pada perpustakaan sekolah SMPN 1 Nan Sabaris adalah layanan baca ditempat saja yang dibuka setiap hari senin sampai dengan hari jumat 
dari pukul delapan pagi sampai pukul satu siang, sedangkan untuk waktu istirahat petugas siswa tetap diperbolehkan masuk keruang perpustakaan untuk membaca buku dengan catatan siswa harus menjaga kebersihan ruang perpustakaan.

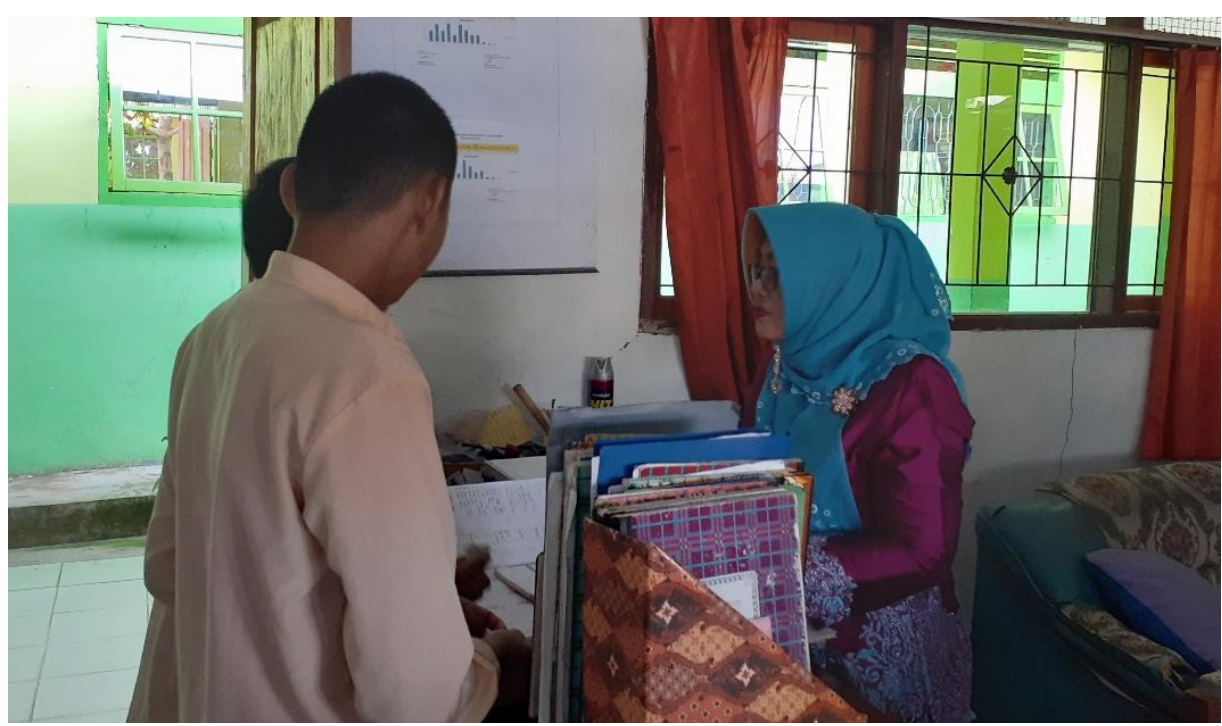

Gambar 1. Layanan peminjaman buku pada perpustakaan sekolah SMPN 1 Nan Sabaris

Kurangnya jumlah kunjungan siswa ke perpustakaan sekolah hal ini terlihat dari buku kunjungan yang diisi oleh siswa yang datang keperpustakaan. Jumlah peminat yang datang setiap hari ke perpustakaan tidak lebih dari 20 pengunjung setiap minggunya yang datang keperpustakaan sekolah dari 627 jumlah keseluruhan siswa. Dari hasil wawancara dengan beberapa siswa kelas sembilan mengatakan mereka malas datang keperpustakaan karena dalam perpustakaan tidak ada yang bisa dilakukan selain membaca. Sehingga kegiatan yang ada disekolah dirasakan sangat monoton dan tidak bervariasi. Hal ini tentu bisa kita rasakan dari aktivitas siswa yang dimulai dari jam tujuh pagi hingga sore hari mereka tidak lepas dari belajar dan membaca.

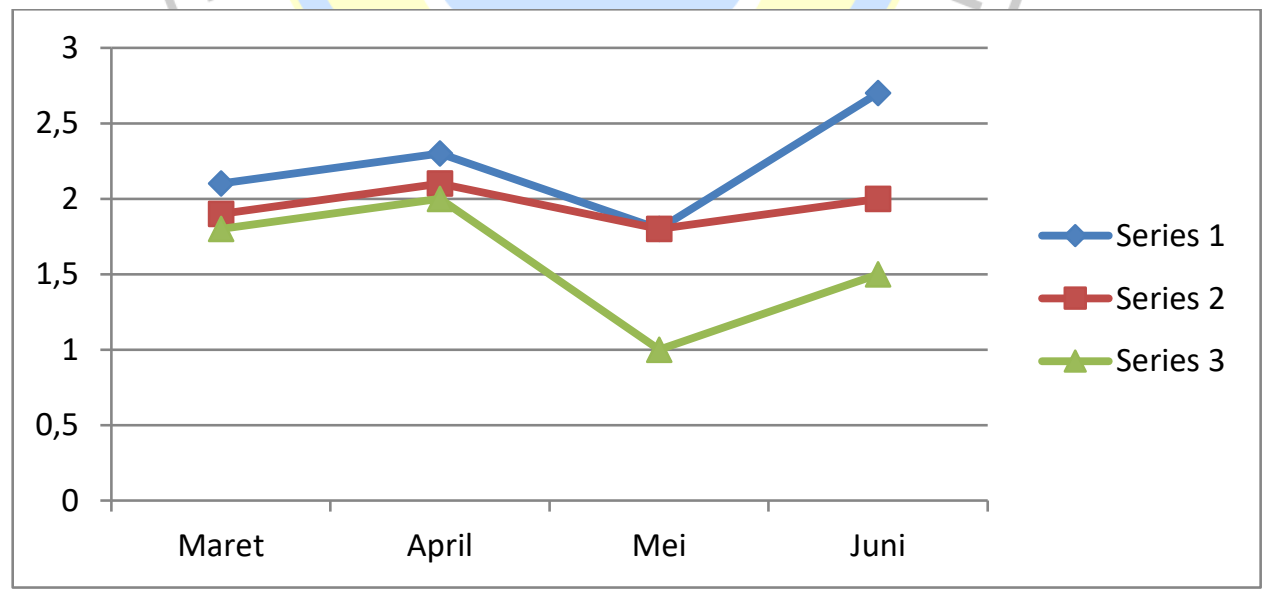

Gambar 2. Statistik Pengunjung Perpustakaan

Dari statistik kunjungan siswa ke perpustakaan sekolah tersebut di dapat dari pengelola perpustakaan sekolah SMPN 1 Nan Sabaris, data yang diambil adalah data penunjung empat bulan terakhir pada tahun dua ribu Sembilan belas, dari data statistik tersebut dapat dilihat sedikitnya jumlah peminat yang datang keperpustakaan, dari data statistik tersebut tidak lebih dari dua puluh orang pengunjung yang datang keperpustakaan dan menggunakan fasilitas perpustakaan. 


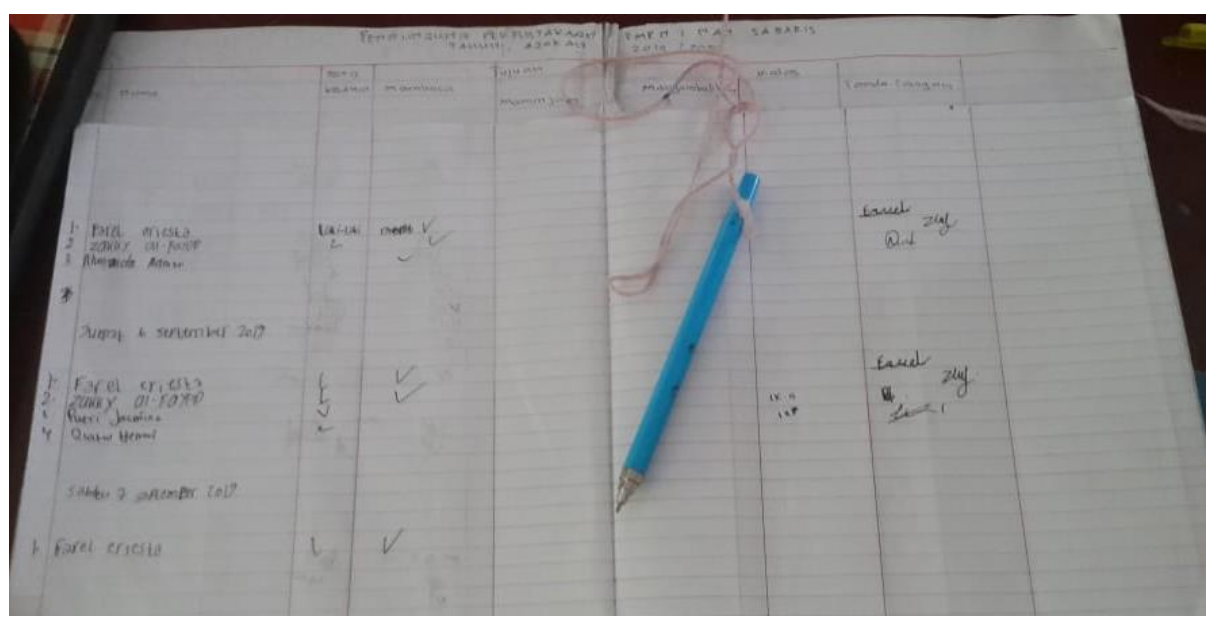

Gambar 3. Statistik Pengunjung Perpustakaan

\section{Metode Pelaksanaan}

Berdasarkan berbagai permasalahan mitra yang telah diuraikan sebelumnya, maka metode yang ditawarkan untuk menyelesaikan persoalan pada layanan perpustakaan sekolah SMPN 1 Nan Sabaris adalah melalui beberapa tahapan sebagai berikut. Pertama, Membuat layanan MakerSpace untuk siswa di Perpustakaan Sekolah SMPN 1 Nan Sabaris, Kecamatan Nan Sabaris, Kabupaten Padang Pariaman dengan melakukan penambahan seperangkat komputer berupa laptop. Kedua, Melakukan pengisian software photoshop, software coreldrow dan software google scetcup. yang bisa digunakan secara offline. Ketiga, Membuat panduan penggunaan software photoshop, software coreldrow dan software google scetcup. Keempat, Melakukan softskill learning kepada pengelola perpustakaan sekolah SMPN 1 Nan Sabaris dalam menggunakan software photoshop, software coreldrow dan software google scetcup. Kelima, Memberi pelatihan kepada siswa sekolah yang merupakan perwakilan dari kelas 8 dan kelas 9 dalam menggunakan software photoshop, software coreldrow dan software google scetcup. Pelaksanaan kegiatan ini dilaksanakan selama tiga hari yang dimulai dari tanggal 29 sampai 30 Agustus dan tanggal 01 September 2019. Adapun khalayak yang mejadi sasaran dalam kegiatan ini adalah pengelola perpustakaan sekolah SMPN 1 Nan Sabaris dan siswa sekolah sebagai pengguna perpustakaan sekolah.

\section{Hasil dan Pembahasan}

\section{Menambah Jenis Layanan Perpustakaan Sekolah}

Layanan perpustakaan biasanya terdiri sari layanan sirkulasi yang digunakan untuk layanan peminjaman dan pengembalian dan layanan referensi yang digunakan untuk layanan baca ditempat. Pada perpustakaan sekolah biasanya hanya ada satu layanan yaitu layanan sirkulasi saja, dan itu pun buku-buku yang disediakan sangat terbatas, jarang sekali sekolah-sekolah memiliki koleksi pengayaan seperti koleksi novel dan sejenisnya. Oleh sebab itu, tim pengabdi melakukan perombakan layanan yang sudah ada pada perpustakaan sekolah SMPN 1 Nan Sabaris untuk menambah sebuah ruangan yang disebut dengan layanan makerspace. Pada layanan ini, siswa disekolah datang keperpustakaan tidak hanya membaca buku ketika ada tugas sekolah dari guru, akan tetapi mereka datang ke perpustakaan bisa mengembangkan kemampuan dan skill yang mereka miliki. Pada layanan makerspace ini disediakan:

a. Sebuah ruangan untuk digunakan sebagai layanan makespace. Dalam hal ini pihak sekolah dan pihak perpustakaan yang berperan untuk menyediakan ruangan.

b. Menyediakan seperangkat Komputer berupa laptop yang berukuran 15 inci. Dalam hal ini tim memilih perangkat yang berukuran kapasitas isi yang besar karna akan digunakan untuk penginstalan software kreatifitas yang akan diguanakan oleh siswa untuk mengembangkan ide dan kreatifitas mereka. 
c. Menginstalkan software photoshop, software coreldrow dan software google scetcup. Pada laptop yang sudah disediakan. software photoshop, software coreldrow dan software google scetcup ini bisa digunakan oleh siswa disaat offline. Jadi tidak perlu menggunakan jaringan internet sehingga memudahkan siswa dalam penggunaannya.

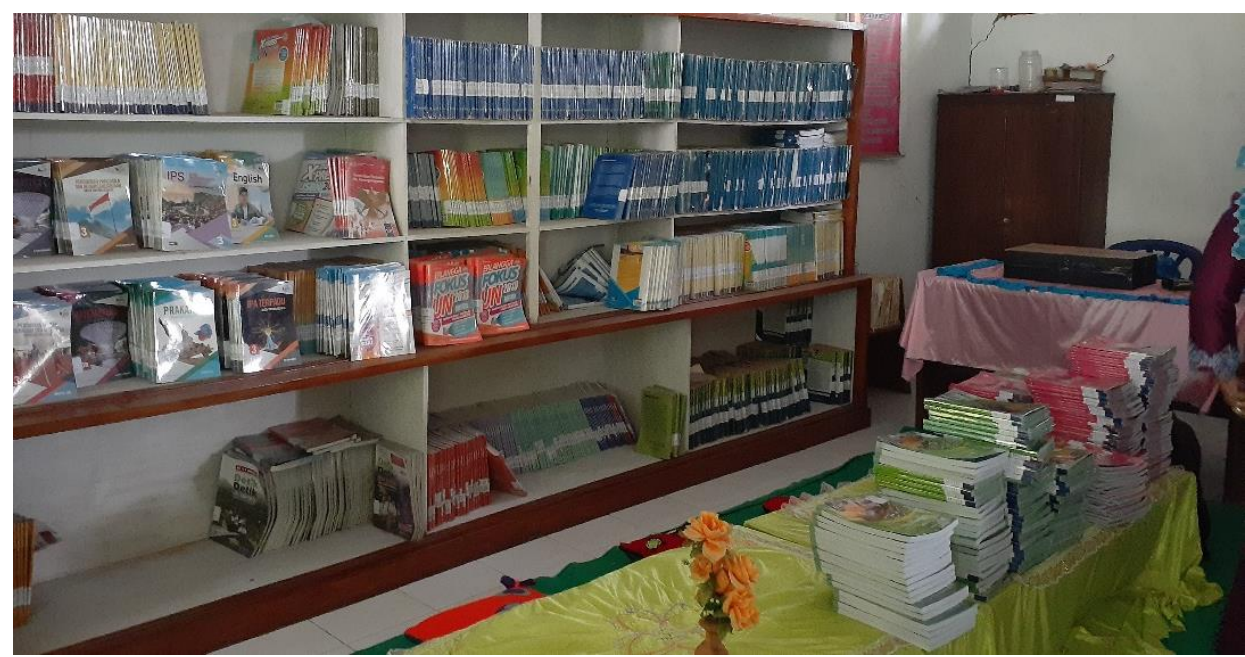

Gambar 4. Penyediaan Ruangan untuk MakerSpace di Perpustakaan SMPN 1 Nan Sabaris

\section{Melakukan Softskill Learning}

Kegiatan ini merupakan media dalam penyampaian materi yang gunakan untuk mengoptimalkan ruang makerspace. Beberapa hal yang disampaikan dalam softskill learning adalah cara menggunakan software photoshop, software coreldrow dan software google scetcup. Peserta yang mengikuti softskill learning adalah pengelola perpustakaan sekolah SMPN 1 Nan Sabaris, dan beberapa orang siswa sekolah yang merupakan perwakilan dari kelas delapan dan kelas Sembilan. Dalam hal ini peserta dibimbing secara individual untuk mengikuti langkah-langkah penggunaan software photoshop, software coreldrow dan software google scetcup.

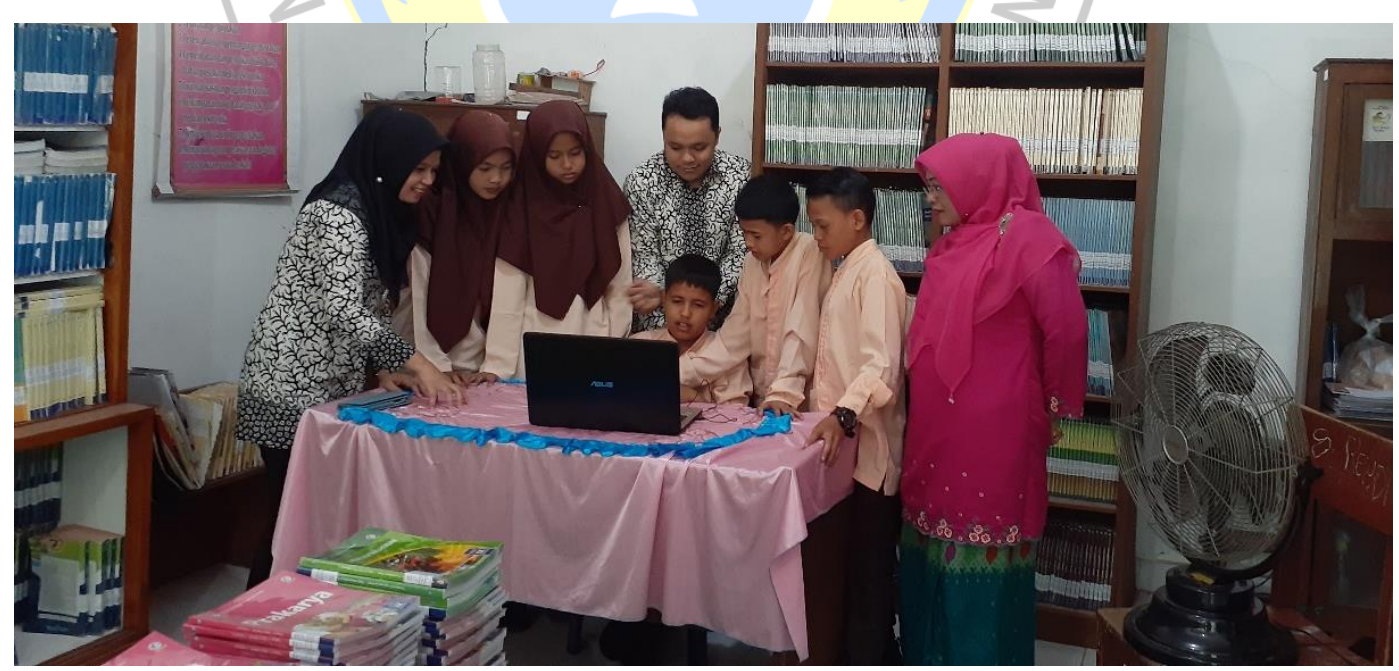

Gambar 5. Proses latihan penggunaan Photoshop

\section{Kesimpulan}

Perpustakaan sekolah SMPN 1 Nan Sabaris merupakan perpustakaan sekolah yang kurang diminati oleh siswa sekolah, tidak banyak siswa yang datang berkunjung setiap bulannya, hal ini disebabkan karena layanan yang disediakan oleh perpustakaan sekolah hanyalah layanan peminjaman 
dan baca ditempat saja. Untuk itu diadakan sebuah trend layanan terbaru yaitu membuat sebuah ruang makerspace untuk perpustakaan sekolah SMPN 1 Nan Sabaris yang bisa dimanfaatkan untuk mengembangkan ide dan kreatifitas siswa. Hasil yang dicapai setelah disediakan ruang makerspace adalah pengguna perpustakaan sekolah SMPN 1 meningkat lima puluh persen dari data statistik penungjung sebelumnya. Setelah melakukan softskill learning dengan pengelola perpustakan sekolah, saat ini pengelola perpustakaan sekolah sudah bisa membantu siswa dalam melakukan pengeditan fotofoto dengan menggunakan software photoshop dan software google scetchup yang sudah diinstalkan.

\section{Daftar Pustaka}

Abram, S. (2013). Makerspaces in libraries, education, and beyond. Internet@ Schools, Vol. 20 (2), 1822.

Burke, J. (2015). Making sense: can makerspaces work in academic libraries?. ACRL 2015, Portland, OR, 25-28 March, pp. 497 - 504, available at: www.ala.org/acrl/sites/ala.org.acrl/ files/content/conferences/confsandpreconfs/2015/Burke.pdf (Diakses Tanggal 14 Mai 2015).

Chan, D.L. and Spodick, E. (2014). Space Development. New Library World, Vol. 115 Nos 5/6, pp. 250-262, available at: http://dx.doi.org/10.1108/NLW-04-2014-0042 (Diakses Tanggal 3 September 2015).

Ching, Francis D.K. (2008). Bentuk, Ruang, dan Tatanan. Jakarta: Erlangga

Mann, L. (2018). Making a Place for Makerspaces in Information Literacy. Reference \& User Services Quarterly, 58(2), 82-86. Retrieved from http://search .ebscohost.com/login.aspx? direct $=$ true $\& \mathrm{db}=1 \mathrm{xh} \& \mathrm{AN}=134186679 \&$ site $=$ ehost-live

Massis, B.E. (2014). What's new in libraries. New Library World, 115 (5), 285 - 288.

Pisasrski, Alyssa. (2014). Finding a place for tween; Makerspace and Libraries. Fall: Children and Libraries.

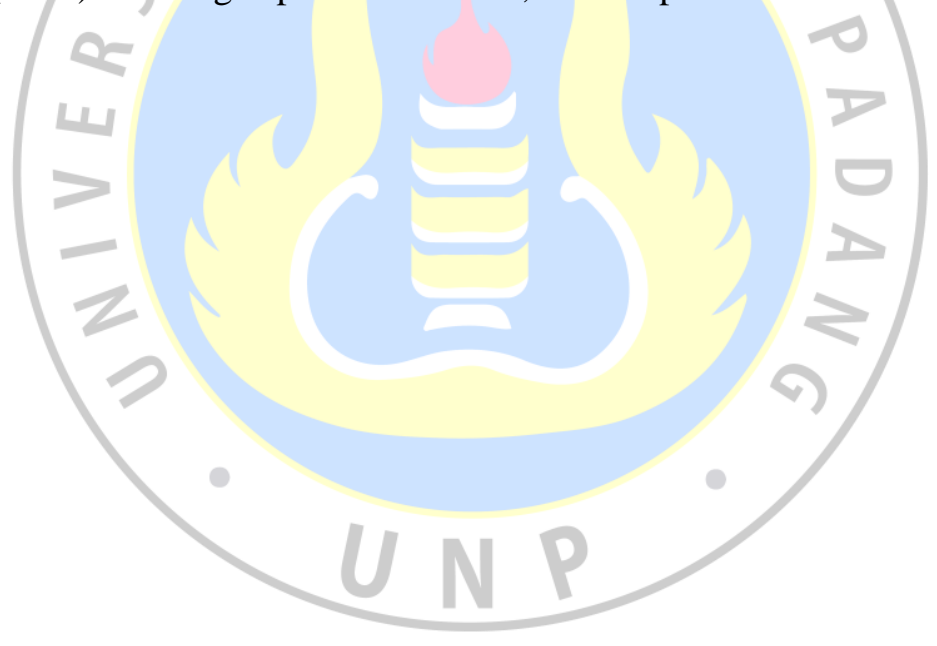

